\title{
PARTICIPATION IN DEBATE: A QUALITATIVE ASSESSMENT OF THE ANDALUSIAN PLAN FOR HIV/AIDS
}

\author{
Eugenia Gil Garcíaํ, Jussara Gue Martini², Francisco Javier Mercado-Martínez², Francisco Garrido Peña
}

${ }^{1}$ Ph.D. in Nursing. Professor, Nursing Department, Universidad de Sevilla. Sevilla, Spain. E-mail: egil@us.es

${ }^{2}$ Ph.D. in Nursing. Professor, Nursing Department, Universidade Federal de Santa Catarina. Florianópolis, Santa Catarina, Brazil. E-mail: jussarague@gmail.com

${ }^{3}$ Ph.D. in Social Sciences. Professor, Public Health Department, Universidad de Guadalajara. Guadalajara, Mexico. E-mail: fjaviermercado@yahoo.com.mx

${ }^{4}$ Ph.D. in Philosophy. Professor in Morale, Department of Philosophy of Law and Politics, Universidad de Jaén. Jaén, Spain. E-mail: fpena@ujaen.es

ABSTRACT: This paper aims to analyze the perspectives and meanings of social participation for the participants in a health program. A qualitative evaluation was conducted on the Andalusian Program against HIV/Aids and other sexually transmitted infections. The participants were selected through a theoretic sample: 20 HIV carriers, 19 representatives and volunteers from anti HIV associations and six administrative representatives. The information was obtained through semi-structured interviews and triangle groups; content analysis was performed. Participation has different meanings to the participant groups. HIV carriers consider it should be accomplished by communication mechanisms, support and prevention; association members consider it a right and a tool to change health policies, while two conceptions coexist among administrative representatives. The encouragement of participatory designs is proposed that respect the theoretical diversity and favor interaction based on distinct attitudes.

DESCRIPTORS: Community participation. Qualitative research. Health promotion. Acquired Immunodeficiency Syndrome.

\section{LA PARTICIPACIÓN A DEBATE: UNA EVALUACIÓN CUALITATIVA DEL PLAN ANDALUZ FRENTE AL VIH/SIDA}

RESUMEN: Este trabajo tiene como objetivo analizar las perspectivas y significados que tienen de la participación social los principales actores involucrados en un programa de salud. Se realizó una evaluación cualitativa del Programa Andaluz frente al VIH/Sida y otras infecciones de trasmisión sexual. Mediante muestreo teórico se seleccionaron los participantes: 20 portadores de VIH, 19 representantes y voluntarios de asociaciones antisida y seis representantes de la administración. La información se obtuvo mediante entrevistas semi-estructuradas y grupos triangulares; haciéndose análisis de contenido. La participación tiene significados diferentes para los grupos participantes. Los portadores de VIH consideran que debe concretarse en mecanismos de comunicación, ayuda y prevención; los integrantes de asociaciones la entienden como un derecho y una herramienta para cambiar las políticas sanitarias, mientras que en los representantes de la administración coexisten dos concepciones. Se propone impulsar diseños participativos que respeten la diversidad teórica y favorezcan la interacción desde distintas posturas.

DESCRIPTORES: Participación comunitaria. Investigación cualitativa. Promoción de la salud. Síndrome de Inmunodeficiencia Adquirida.

\section{PARTICIPAÇÃO EM DEBATE: UMA AVALIAÇÃO QUALITATIVA DO PLANO ANDALUZ DE HIV/AIDS}

\begin{abstract}
RESUMO: Este trabalho tem como objetivo analisar as perspectivas e significados da participação social para os príncipais atores envolvidos em um programa de saúde. Realizou-se uma avaliação qualitativa do Programa Andaluz frente ao HIV/aids e outras infecções de trasmissão sexual. Mediante amostra teórica foram selecionados os participantes: 20 portadores de HIV, 19 representantes e voluntários de associações anti HIV/aids e seis representantes da administração. A informação foi obtida mediante entrevistas semi-estruturadas e grupos triangulares; utilizou-se análise de conteúdo. A participação tem significados diferentes para os grupos participantes. Os portadores de HIV consideram que se deve concretizar os mecanismos de comunicação, ajuda e prevenção; os integrantes de associações entendem a participação como um direito e uma ferramenta para mudar as políticas sanitárias, enquanto que nos representantes da administração coexistem as duas concepções. Se propõe impulsionar os desenhos participativos que respeitem a diversidade teórica e favoreçam a interação desde distintas posturas.
\end{abstract}

DESCRITORES: Participação comunitária. Pesquisa qualitativa. Promoção da saúde. Síndrome de Imunodeficiência Adquirida. 


\section{INTRODUCTION}

The lack of financial resources and the demand for transparency in public management seem to explain the growing interest of health administrations in the incorporation of new relationship strategies with service users. These strategies include the encouragement of public participation and the development of health policy assessment programs. ${ }^{1-2}$ Public participation has been considered from different perspective as an attitude of solidarity, dialogue and concern with the management of collective life, as an organized activity by a group to express needs, demands or defend interests, and also as the organized effort to enhance the control of resources or as an empowerment strategy of citizens with a view to equitable access to public resources. ${ }^{3-7}$

The interest in participating in the health context is materialized in the importance health systems attribute to the establishment of networks of confidence and cooperation between users and professionals. In the Spanish case of Andalusia for example, concrete measures included the implementation of complaint boxes, user care workshops, care telephone lines and instruments to enhance collective participation, such as patient and family groups. In general, the associations defend and promote the collective interests and enable the patients and family members through knowledge and disease management. In the antiaids movement, the associations usually develop other functions, such as awareness raising campaigns for vulnerable populations, fighting against the social stigmatization of the disease, implementing prevention and health promotion policies or establishing support networks. ${ }^{8-12}$

On the other hand, evaluation, as a process to get to know and measure the outcomes of an intervention or program, has been applied in the health area since the 1950 's ${ }^{13}$ At first, the evaluations were based on expert knowledge and practices and centered on efficacy, efficiency and cost reduction, with particular emphasis on measurable and quantifiable aspects. In the early 1990's, however, new evaluation initiatives emerged, interested in local knowledge, dialogue and participation. These evaluations mainly incorporate different stakeholders' viewpoints and are concerned with sectors that are traditionally excluded in health and social terms, at the same time as they call for local health reforms from an interdisciplinary perspective. ${ }^{14}$
These evaluation practices have received multiple names, among which qualitative assessment (QA) is highlighted. Over the years, these have served to assess sectorial health services and specific public health programs or policies. ${ }^{15-20}$ The goals include the democratization of institutions, the empowerment of the actors and the increased transparency of the same participatory processes. ${ }^{21}$

Despite the increasing expansion of qualitative assessment, little debate on this method happens in the academy and few scientific articles are published. On most occasions, they continue in the grey literature, without these participatory local experiences helping to understand and transform the processes developed in other geographic contexts. Therefore, the objective in this study is to analyze the perspectives and meanings of social participation for the main stakeholders involved in the Andalusian Plan against HIV/Aids and other sexual transmitted infections (PASIDA).

\section{METHOD}

This study is part of a broader research aimed to designing an institutional proposal to enhance the participation and empowerment of carriers and patients, as well as the co-accountability of associations, in the PASIDA in Andalusia, Spain. The PASIDA is a program that adapts the proposals of the Spanish National Aids Plan to the Andalusian social reality in Spain. Its goals are cross-cutting and comprehensive. The objective of the plan was to respond to scientific-medical and social challenges, such as reducing the diagnostic delay, decreasing the rootlessness, stigma and social isolation and improve the level of autonomy of the infected people. The Plan was elaborated with a high degree of participation, including professionals from the Andalusian Public Health System (SSPA), as well as social entities and organizations and stakeholders. This report corresponds to the first part of the assessment, centered on the perspectives and meanings of the participation in three groups.

A qualitative assessment of the PASIDA was undertaken. Through theoretical sampling, three groups were selected: HIV carriers or aids patients not affiliated with the associations; Representatives and volunteers of the associations fighting against HIV and Representatives of the health administration. Semistructured interviews were held to know the three groups' opinions, as well as Triangular Groups (TG) to know the discourse of 
the volunteers who participate in the associations.

To select the sample of the non-associated carriers, the sex, contamination route and province of residence were considered. For the sample of association representatives, the province and type of associations were taken into account (local, provincial or regional). To design the sample of management representatives, the organizational structure was considered. In all TG, one volunteer from an association related to the gay movement participated, as well as another person affiliated with the movement against drug addiction.

In total, 45 people participated: 20 nonassociated HIV patients (12 men: 6 sexually contaminated and 5 through intravenous heroin consumption; 1 by transfusion; 8 women: 5 sexually contaminated and 3 by intravenous heroin consumption). 19 representatives and volunteers from anti-aids associations (10 representatives from associations: 8 from provincial organizations, 2 from regional federations) and 3 TG with volunteers (1TG of a support organization against drug addiction, 1TG of a federation of provincial associations, 1GT of an association of gays/lesbians); 6 representatives from the administration (1 Head of Participation Service of Health Council, 1 Head of Health Section. Provincial Health Delegacy. Seville, 1 Head of Health Service of Provincial Health Delegacy. Malaga, 1 Head of Health Service of Provincial Health Delegacy. Granada, 1 Sub-Director of Care Organization and Cooperation of the Andalusian Health Service, 1 expert technician from the Health Council).

The fieldwork was undertaken between January and June 2010. All interviews were recorded with preliminary consent and transcribed by specialized staff, who followed the recommendations regarding intonation and silence in the oral discourse. ${ }^{22}$ The content analysis technique was used, starting with a preliminary reading of the transcripts, followed by the creation of preliminary bodes that were grouped in categories. ${ }^{23}$ The researchers triangulated the categorization and definition process of the categories. The syntactic, semantic and pragmatic levels were considered, that is, the order of appearance, the meanings the distinct actors attribute to the analysis categories and the theories related to the participation. ${ }^{24}$

Approval for the project was obtained from the Research Ethics Committee at the School of Nursing, Physiotherapy and Podiatry, Universidad de Sevilla. To preserve the participants' ano- nymity, they were identified as follows: Non-associated Aids Carriers: W (women) and M (men), followed by the interview number. Association representatives and volunteers: $\mathrm{R}$ followed by the interview number; and administration representatives AR followed by the interview number. At the start of the interview, the participants were informed about the objectives and signed a document to consent with the recording and the use of the data for research purposes.

\section{RESULTS}

\section{Participation according to non-associated HIV/Aids carriers}

The HIV patients who were not associated with associations have a vague idea about participation in the PASIDA. They generally link it to the accomplishment of activities in the associations and do not mention participation for other causes, such as the implementation forums of health policies. They consider that the anti-aids association movement does important work in infection prevention and that everyone has received information about some of its activities. Nevertheless, many patients show mistrust towards the associations and some reject participating as volunteers. On some occasions, they do not distinguish between anti-aids associations and associations against drug addiction. They also demand further information about how and where to participate (Figure 1-a).

The majority believes that engaging in the associations and communicating their disease experience offers multiple social and individual advantages. Among the first, the encouragement of prevention and health promotion activities stands out: mainly for those who have just fallen sick (W-12); advice and support to newly contaminated patients: advise, or explain, or say: look, if you have a cold you will not die now (M-11). Being part of a community of peers makes it easier for them, at the individual level, to better cope with the problems related to the infection and overcome the difficulties related to the lack of institutional support: if talk to him about... because he is going through the same problem as I, he has the same disease (M-1); the lack of confidence in other people and the secrecy they find themselves obliged to maintain in order to avoid the social stigma: I think that, through associations, there is more support [...] because individually, 
I believe you don't get anywhere (W-1). To engage in the association movement, however, they would need further information about how and where to participate: I need information. [...] that there are these place, what it is about, how I can help another person (M-11).

\section{Figure 1 - Results - opinions of stakeholders about participation in PASIDA. Andalusia - Spain, 2010}

\section{1-a: Non-associated carriers}

- Have little information about the participation channels the PASIDA offers.

- Do not have an explicit demand for participation, but for information, help, advice, listening.

- Offer to participate as volunteers in information campaigns.

- The preferred participation routes favor anonymity and intimacy (telephone, e-mail, interviews).

- Among the most positive effects of participation, they value:

- Being listened to.

- Increased self-esteem.

- Mutual help among patients. Therapeutic community.

- Information on preventive measures.

- Information about channels, strategies and institutions that fight against aids.

- Demand that they information they receive comes from health staff.

- Express doubts on the utility of participation (fear that decisions will not be complied with) and on the costs of participation (too much time and effort).

- Are afraid of too much bureaucracy.

- Mistrust associations as channels that favor social stigma and consider that some associations are not serious.

\section{1-b: Association representatives and volunteers}

- Consider participation as a right and a tool of civil society to change health policies.

- Consider that associations have three functions:

- Covering: do services the health administration should perform.

- Mediating: serve as interlocutors between civil society and health administration.

- Mutual support: help and cooperation among patients.

- They find the mediating function most relevant.

- Positively value a territorially decentralized design of participation spaces.

- Positively estimate the participation process in the elaboration of participatory proposals.

- Consider a program of material and institutional stimulus necessary for participation.

- Believe that the weight of the administration in the participation designs should be smaller.

\section{1-c: Administration representatives}

- Very positively value public participation. Consider that we are going through a moment of change in the relation between the health administration and patients.

- Consider that there are two conceptions of public participation in health:

- A classical form transmitted through the associations.

- A more plural, qualitative, informal and direct new and emerging form. Bet on the latter through a gradual transition process.

- Consider that the participation of patients and associations linked to HIV offers the following advantages:

- Helps to improve the services.

- Permits reaching spaces where the administration does not arrive.

- Enhances available information, including about abuses and failures.

- Favors management transparency.

- Detect perverse effects of health promotion campaigns.

- Enhances the administration's perspective.

- Consider the use of ICT's and online participation forms as very positive.

- Detect obstacles and negative inertias in the administration in view of new public participation forms.

- Believe that the participation mechanisms should be stable, autonomous and generate confidence.

Some reject participating in associations for two reasons. One is related to the social stigma of the disease and their need to normalize the situation: normalize this disease [...] because... if I had diabetes, it would be easier for me to say: I am diabetic to any person, and they would see it as something normal. But I can't say around here that I'm seropositive, right? Because imagine yourself 
(M-3). Others link it to the lack of seriousness of the associations they know. They consider that the funding these associations receive from the public administration goes against the members' altruistic engagement: we simply dedicate our free time to do something for everyone to stay afloat, now if there's money, money we don't get involved (M$3)$. As observed, the interviewed women relate less with the associations: no, I have never been to any (W-4) and the heterosexual men criticize the associations against HIV / Aids because they are generally associated with drugs. The homosexuals, in turn, criticize what they consider as the frivolity of some gay associations.

Despite the limited confidence in the associations, some interviewees offer to serve as volunteers. They condition their participation to the seriousness of the structure and the usefulness of the action. They find themselves prepared to offer their knowledge and help other people, because I find myself capable of, to be able to tell many things to the people who are, they need psychological help because you've got this, the HIV (M-4). They believe that, in the retired situation they are in, they could accomplish participatory activities: for me, what I want, as I am retired. [...] all of this makes me join, really [...] also, if you put me up as an organizer, I organize (M-2). Some interviewees talk in the first person singular and manifest a more active attitude, they want to organize activities, while others use the second person singular and candidate themselves to learn and accomplish simpler tasks. They also want to participate in information campaigns, to monitor other patients and to take part in prevention campaigns against the dissemination of the infection: telling my experience or doing an intervention [that] contributes to save lives or for us to use precaution measures, but that should be supported by the ministry of health, of course, because they are the first stakeholders (M-3).

The HIV patients who do not participate in the associations also mix up the anti-aids associations with those fighting against drug addiction, mix up their objectives and do not clearly see the space of each. As a result of this mix-up, patients who consider themselves detached from addiction reject participating in associations and do not want to relate with other people who consume psychoactive substances: no, because they take drugs and I'm not interested in that (M-1).
When asking about the participation routes they consider most convenient, the majority prefers the privacy of an interview, the telephone, e-mail and to a lesser extent meetings or public assemblies. They want to give their opinion through individual routes from you to you, provided that they are serious and useful: in private (W-11); do a kind of study, I don't know, like that you are doing and knowing what the needs are because there are many (M-3); use e-mail for example [...] and telephone calls (M-6).

\section{Participation according to association representatives and volunteers}

The NGO members consider participation as a right that contributes with recommendations, ideas and information, but also as a tool to denounce discrimination, claim for equality and improve the quality of life. They also consider that it enables people to cope with the disease and favors opinion making and experience exchange (Figure 1-b).

On many occasions, they consider that participation is a vehicle the civil society has at its disposal to achieve social exchanges that benefit their own interests. They consider that the activities they accomplish are a public service that responds to social demands the health and social system cannot respond to, as one of them appoints: we occupy a space [...] provide a public service (R-2).

According to the study participants, the anti-HIV/Aids associations have three types of functions related to participation: covering, mediating and mutual support. The covering function refers to the fact that they cover demands the social-health system does not cover: we perform very important social work, which the Administration should do but we supply it (R-8). The mediating function refers to the intermediation tasks. That is, that the associations serve as channels for the social demands and as mediators that redistribute the resources to the civil society. The association representatives find this function the most important. In this respect, one of them says: an NGO emerges from a need. So we are mediators between the need and the resources, which is the public Administration (R-4); because we really work with direct contact, day to day, with the people, so reflect that in some way, these experiences And which can reach the administrations ( $\mathrm{R}-9$ ). 
The mutual support function is what makes the associations most meaningful. All of the associations are aware that they need to attend to, fight and cover the needs of the patients and stakeholders which the public entities cannot offer, as one of them observes: [...] we are a group of people who fight against discrimination (TG-1); it is extremely clear to us that the reality from the streets does not reach them (R-9).

According to their members, participating in the associations produces new spaces of interrelation, permits conquering new rights for the population and fighting for equality and non-discrimination. The associations accomplish educational activities and activities to prevent risk conducts and cooperate with public initiatives like the HIV test: I address themes like education. I am responsible for educational policies and because in Jaén, we are in charge of distributing condoms, do some specific workshops for the young people in the association about prevention, about risk conducts and we do the HIV tests too (R-6).

\section{Participation according to management representatives}

The public agents' discourse reflects the importance they attribute to civil participation (Figure 1-c). They are aware that there is a momentum for a change in the way of understanding and coping with the social demands in the field of health and participation. Some comments clearly present the theme: defining it from below; and the more participation we give to people, the surer we get that the participation will be successful. That is why it is very important for us to understand, the people on top and the Management, that the spaces have to be increasingly open (AR-1); that when I. I said but yes they are defending the same group... but of course they join with totally distinct interests, and for me, participation belongs to a world that ... I love it (AR-6).

Two forms of understanding and defining participation are observed, a more classical conception that considers that the administration grants participation to the different groups and another conception of emerging, richer, informal and direct participation, characterized by the defense of the group. In both cases, however, the administrative agents bet on a change in the participation model. They consider that the transition process should be slow, in order to favor the consolidation and trust in the new models. In their discourse, elements emerge that make them mistrust, the most relevant is the associations' representativeness, according to some of them: what I call classic, focused on cooperation and distribution of help from the Administration to the associations... and on the other hand that linked to the new comprehensive plans (AR-3); the associations or representatives themselves look at you. Don't they? To the person bringing the Plan, to the person in charge, the technician, the officer on duty, as the person who, kind of knows things when actually they should speak out for themselves, right? The only thing we'd have to do actually is facilitate things (AR-5).

The people interviewed at the public entities mention advantages of public participation related to HIV / Aids. They consider that participating helps to improve the services; it permits reaching spaces that are hard to access for the administration; enhances the available information when discovering abuses committed in the private space of a consult; favors transparency; defines problems and discovers perverse effects of campaigns or policies that are carried out. In short, they consider that the participation expands the institution's viewpoints as it enhances the understanding and control of the situation surrounding the HIV/Aids. They are by the way those that best reach them. Prostitution, how will we reach that? (AR-2). Participation supposes for the entire process the contribution from an external value, to be able to better manage the complexity (AR-5). They detect things in a closed environment of a consult, which the system does not detect (AR-1).

\section{DISCUSSION}

The perspectives and meanings of the three groups of stakeholders investigated, non-associated patients, associations and administration regarding the participation process related to the PASIDA are varying. The differences are related to the conception of what participation should be and the channels and participatory strategies that should guide the PASIDA.

The non-associated HIV patients consider that the participation should materialize in communication, listening, help and prevention mechanisms; the associations relate the participation with a standardizing and democratic dimension and consider that participation combines the ex- 
ercise of a right and the possibility of making joint decisions. The administrative representatives, in turn, center participation on a conception related to the change of the health management model. This divergence strengthens the thesis about the multiple meanings of the public participation ${ }^{3}$ concept and expresses the disparity of interests in each social group..$^{25}$

As regards the participation channels and strategies, non-associated HIV patients have little information and are sensitive to the associations' work, fundamentally related to the sensitization strategies of vulnerable populations ${ }^{9}$ and acting against the social stigmatization of the disease. ${ }^{10}$ The HIV/ Aids patients and carriers ask that they be listened to and taken into account, especially those who feel most vulnerable. ${ }^{11}$ The associations' perspective on participation is more related to the organized activity of a group with a view to expressing needs, demands or defending common interests $^{4}$ and as a strategy to gain positions of power that permit better access to the resources. ${ }^{7}$ The representatives of the administration, in turn, positively value the participation of patients and family members by improving the health policies and enhancing the control and efficacy of the resources. ${ }^{5-6}$ They consider that the participation mechanisms should be expanded, furthering stable participation strategies and, at the same time, intending to incorporate new information and communication technologies.

On the other hand, the singularity of the participation process should be taken into account with regard to the HIV infection. The link of the disease with the so-called risk groups and its infectious nature have given rise to a strong social stigma loaded with negative connotations. ${ }^{26}$ This conditions and singularizes the participation process and, also, generates contradictory demands and strategies. The demand for empowerment, standardization and visibility of the HIV patients goes against the demand for privacy and protection of the patient' intimacy, but both live together simultaneously. The social stigma of the disease, in turn, acts as a limit that hampers the HIV carriers' participation, but minimizing it is also an objective of all participation programs.

\section{CONCLUSIONS}

The qualitative assessment of the Andalusian Aids Plan has manifested the range of viewpoints in each social group and, also, the groups' internal homogeneity. This indicates the need for a participatory proposal that respects the diversity and, at the same time, favors the complementary and synergic interactions among the social groups engaged. The participation in the PASIDA, besides being plural, should articulate and coordinate other participation mechanisms and routes that avoid the biases and distortions ${ }^{27}$ of a system that exclusively rests on the associations.

With a view to democratic interactions among the groups, the standards and rules of the participatory entities need to be outlined and procedures need to be established to verify compliance with the agreements. In that sense, the creation of a Network of Social-Health Sensors (Red de Sensores Sociosanitarios - RSS) is proposed, consisting of health professionals who are in charge of establishing a network of information and expression channels of the male and female patients, in the way the epidemiological alert networks are organized and operated. ${ }^{28}$ They would have a double mission: on the one hand, they would be in charge of articulation the information they need and demand. In parallel, the autonomy of the participatory entities and the use of information and communication technologies in the participatory processes would need to be enhanced.

Finally, the inclusion of the voices and discourse of the stakeholders in the assessment processes of public policies is one of the novelties in emerging assessment practices. The use of qualitative social research strategies strengthens the utility of the assessments. Nevertheless, the interdisciplinary articulations that should guide the entire qualitative assessment process are in an initial stage. Continuous work is needed in the coordination and integration of the strategies and disciplines and in the efforts to publish the qualitative assessment results in the form of scientific papers, so that the scientific community values and integrates them.

\section{REFERENCES}

1. Organização Mundial da Saúde. Quality of care: a process for making strategic choices in health systems [página na internet]. Geneva $(\mathrm{CH})$ : OMS; 2006 [acceso 2011 Nov 30]. Disponíble en: http:// www.who.int/management/quality/assurance/ QualityCare_B.Def.pdf 
Gil García E, Martini JG, Mercado-Martínez FJ, Garrido Peña F

2. European Patient's Forum [página na internet] 2011 [acceso 2011 Des 06]. Disponible en: http:/ / www. eu-patient.eu/

3. Delgado Gallego ME, Vázquez Navarrete ML, Zapata Bermúdez Y, Hernán García M. Participación social en salud: conceptos de usuarios, líderes comunitarios, gestores y formuladores de políticas en Colombia: una mirada cualitativa. Rev Esp Salud Pública. 2005 Nov-Dic; 79(6):697-707.

4. De Schutter A. Investigación participativa: una opción metodológica para la educación de adultos. Michoacán (MX): CREFAL; 1986.

5. Wolfe M. La participación: una visión desde arriba. Argentina (AR): CEPAL; 1984.

6. Sánchez M. Metodología y práctica de la participación. Madrid (ES): Editorial Popular; 1986.

7. Rapapport J, Swift C, Hess R, editors. Studies in empowerment. Binghamton (US): Haworth; 1984.

8. Consejería de Salud de España. Junta de Andalucía. Observatorio de Salud y Medio Ambiente de Andalucía. III Plan Andaluz de salud [online]. 2003-2008 [acceso 2011 Dez 08]. Disponible en: http://www.osman.es/contenido/profesionales/ articulo_3_plan_andaluz_salud.pdf

9. Veloso VG, Portela MC, Vasconcellos MTL, Matzenbacher LA, Vasconcelos ALR, Grinsztejn B, et al. Testagem anti-HIV em mulheres grávidas no Brasil: taxas e preditores. Rev Saúde Pública. 2008 Out; 42(5):859-67.

10. Seoane L. Evaluación cualitativa de una campaña de promoción del uso del preservativo en la población adolescente y juvenil de la Comunidad de Madrid. Rev Salud Publica. 2002 Set-Oct; 76(5):509-16.

11. Franco Giraldo A, Alvarez-Dardet C. Derechos humanos una oportunidad para las políticas públicas de salud. Gac Sanit. 2008 May-Jun, 22(3):280-6.

12. Alexandre AMC, Maciel K, Fernandes APP, Perex AM, Wolff MFM, Mazza VA. La red social de apoyo en Brasil: grupos y líneas de investigación. Texto Contexto Enferm. 2011 Abr-Jun, 20(2):241-6.

13. Tetelboim C. Evaluación de propuestas internacionales y regionales en el decurrir de las políticas y las instituciones de salud en América Latina. En: Mercado-Martínez FJ, Mercado A. Evaluación emergente de políticas y programas de salud: avances y desafíos en América Latina. Mérida (MX): UADY/CUMEX; 2010. p.25-50.

14. Mercado FJ, Bosi MLM, Hernández-Ibarra E. Modelos emergentes de evaluación: ¿Contribuciones a las reformas sanitarias en América Latina? En: Mercado FJ, Mercado A. Evaluación emergente de políticas y programas de salud: avances y desafíos en América Latina. Mérida (MX): UADY/CUMEX; 2010. p.51-78.

15. Dzuba I, Calderón R, Bliesner S, Luciani S, Amado F, Jacob M. A participatory assessment to identify strategies for improved cervical cancer prevention and treatment in Bolivia. Rev Panam Salud Publica. 2005 Jul, 18(1):53-63.

16. Campos R, Furtado J. Entre a saúde coletiva e a saúde mental: um instrumental metodológico para avaliação da rede de Centros de Atenção Psicossocial (CAPS) do Sistema Único de Saúde. Cad Saúde Pública. 2006 May; 22(5):1053-62.

17. Arzate S. Evaluación de un programa de lucha contra la pobreza extrema en México desde una perspectiva cualitativa y microsociológica. Rev Vzlana Soc Ant. 2006, 16(45):138-61.

18. Bursztyn I, Ribeiro J. Avaliação participativa em programas de saúde: um modelo para o Programa de Saúde do Adolescente. Cad Saúde Pública. 2005 Jan-Mar; 21(2):404-16.

19. Minayo MC. Abordagem antropológica para avaliação de políticas sociais. Rev Saúde Pública. 1991 Jun; 25(3):233-8.

20. Moysés S, Krempel M. Avaliando o processo de construção de políticas públicas de promoção de saúde: a experiência de Curitiba. Ciênc Saúde Coletiva. 2004 Jul-Set; 9(3):627-41.

21. Tejada LM, Mercado-Martínez FJ. Entre la disponibilidad y el acceso a la atención médica. La mirada de los enfermos crónicos en condiciones de pobreza. Salud Colectiva. 2010 Ene-Abr; 6(1):35-45.

22. Casimilglia H, Tusón A. Las cosas del decir: manual de análisis del discurso. Barcelona (ES): Ariel Lingüística; 2002.

23. Hsieh HF, Sahnnon SE. Three approaches to qualitative content analysis. Qualit Health Res. 2005 Nov; 15(9):1277-88.

24. Krippendorf K. Metodología de análisis de contenido: teoría y práctica. Barcelona (ES): Paidos; 1990.

25. Caballero JJ. La interacción social en Goffman. Rev Esp Investig Socio. 1998; 83:121-49.

26. Aggleton P, Parker R, Maluwa M. Estigma y discriminación por VIH y SIDA: un marco conceptual y bases para la acción [online]. Ginebra (SW): UNAIDS; 2002 [acceso 2011 Dec 07]. Disponible en: http://www.ciudadaniasexual.org/boletin/b1/ Discriminaci\%F3n\%20por\%20VIH.pdf

27. Costa I, Font J. Participación colectiva y revelación de preferencias sobre programas sanitarios: un 
enfoque de sistema sanitario. Gac Sanit. 2005 MayJun; 19(3):242-52.

28. Gil García E, Garrido Peña F, Díaz Sabán S.
Participación y diseño institucional de asociaciones y pacientes de VIH/Sida en Andalucía. Sevilla (ES): Consejería de Salud; 2011. 